\title{
CHRISTIAN MATERIALISM AND THE QUEST FOR HUMAN PERSONHOOD
}

\author{
MiKAEL LEIDENHAG* \\ Uppsala University
}

\begin{abstract}
This paper offers a critical exploration of philosopher Kevin Corcoran's proposed Christian Materialism. Corcoran's constitution view claims that we human persons are constituted by our bodies without being identical with the bodies that constitute us. I will critically evaluate this view and argue that Corcoran has not successfully managed to ground a first-person perspective and intentional states in materialism. Moreover, Corcoran's property dualism about mental states and the idea of the causally efficacy of such states seem incompatible with materialism. Corcoran's view of imago Dei is also explored and evaluated. Towards the end of the paper I put forward a brief defense of dualism in light of Corcoran's critique.
\end{abstract}

KEY WORDS: Christian Materialism, constitution view, Kevin Corcoran, reductionism, dualism

\section{Introduction}

How we view human personhood is continuously evolving as modern science challenges and alters our idea of what makes us human. Darwin's theory, many have argued, presented not just a challenge to biblical literalism, but also to our understanding of human nature. Several contemporary scientists and philosophers maintain 'that the person is but one substance-a physical body' (Murphy 1998a:1). If dualism is no longer considered a tenable anthropological standpoint then we must find new ways of conceptualizing human personhood. In light of the perceived problems of a Cartesian dualist ontology, philosophers of mind have proposed a number of alternative positions: reductionism, non-reductive physicalism, emergentism, etc. In theological anthropology, the challenge has been to articulate an account of personhood that can meet the demands of scientific credibility, philosophical coherence, ethical adequacy, whilst staying true to biblical portrayal of humanity.

* Mikael Leidenhag (PhD 2016, Uppsala University, Sweden). Email: mikael.leidenhag@teol.uu.se 
Philosopher Kevin J. Corcoran has argued for a Christian materialist alternative to the soul. This proposal seeks to steer between both a reductive version of materialism and a dualistic account of personhood and the soul. This paper will critically evaluate Corcoran's proposal for theological anthropology. The paper will focus on both the philosophical plausibility of this Christian materialism, as well as the theological cost of basing one's understanding of human nature on a materialist ontology. It will be seen in this paper that Corcoran seeks to make a first-person perspective and intentional states compatible with materialism. However, he does not successfully ground such phenomena in materialism, but leaves both capacities of the mind unexplained. Moreover, it seems as if the causal efficacy of mental states does not sit well with materialism. From a theological point of view, I will argue that Corcoran, given his materialism, is unable to uphold a robust account of imago Dei. This theological cost should make us skeptical of the suitability of materialism for theological anthropology. In the end, I argue that dualism remains a viable option for articulating human personhood.

\section{Christian Materialism and the Path beyond Reductionism and Dualism}

From a Christian point of view, critical reflection on human personhood cannot be reduced to philosophical curiosity. It is an essential task for the theologian to reflect on what makes us truly human and how our personhood relates to the rest of creation. Moreover, this debate is entangled with important contemporary ethical debates, including stem cell research, cloning, and genetic and reproductive technologies. In order to come to an informed decision on what technologies and therapies should be allowed for human beings we need to reflect on what makes a human, human. Moreover, a specific account of human personhood will affect our ideas of life after death, but also the claim that human beings are created in the image of God.

Kevin Corcoran has launched an impressive defense of a materialist conception of human nature. Materialism, according to Corcoran, is favoured by contemporary neuroscience. It is also philosophically coherent and is able to sustain a responsible ethical system that respects the value of life. It is also superior to both reductionism and dualism, according to Corcoran.

The key aspect of Corcoran's materialism is the notion of constitution. The constitution view states that 'we human persons are constituted by our bodies without being identical with the bodies that constitute us' (Corcoran 2006: 65-66). Corcoran exemplifies this with a bronze statue. It is, he notes, 'possible for the mass of bronze to survive changes that would terminate the existence of the statue...' (Corcoran 1999: 1). Moreover, one could destroy the statue, scatter the pieces, while the mass of bronze survives. The bronze 
material could also be moulded into something else without introducing new material. Thus, the statue with its specific attributes is constituted by the mass of bronze, yet it is not identical to it. As Corcoran suggests, the statue possesses particular properties that are not shared by the piece of bronze, and given that they differ in properties they are not identical. Can this constitution thesis be applied on the relationship between personhood and the physical body of a human being? In order to answer this question we must first define what a person is. Corcoran argues that we can articulate a minimalist account of personhood. He writes, 'I think we can say with some confidence that persons (human or otherwise) are, minimally, beings with a capacity for intentional states: believing, desiring, intending, etc.' (Corcoran 1999: 2). Human persons are also constituted by biological bodies, and those bodies are themselves constituted by smaller physical objects, i.e. cells. One can see on reflection that a 'person' and a 'physical body' differ when it comes to properties. Corcoran also suggests that they have different 'persistence conditions'. That is, it is possible for my body to persist, to continue to exist, without having intentional states. Corcoran writes, 'Therefore, there is no conceptual impossibility involved in thinking about my physical organism continuing to exist while completely lacking a capacity for intentional states' (Corcoran 1999: 3). There is nothing about having a physical body in terms of identity conditions that necessarily involves having intentional states and having the capacity for a first-person perspective.

In this way, the constitution view takes us beyond the person-body identity that is associated with a nothing-but materialism. However, Corcoran does not think that this irreducibility of the 'person' takes us in the direction of a dualism. Dualism, argues Corcoran, suffers from several philosophical problems and its ontological claims are incompatible with the deliverances of science. Dualism portrays human beings as composed of a physical body and a non-physical soul. But, there seems to be a tension between dualism, 'on the one hand, and both the neural dependence of consciousness and the seeming irrelevance of a non-physical soul in explaining certain features of our conscious mental life...' (Corcoran 2016: 154). If dualism is true, argues Corcoran, neuroscience should be explanatorily irrelevant as our mental life is located and grounded in a non-physical substrate; but, of course, neuroscience is highly relevant (Corcoran 2016: 156).

How should one understand the imago Dei, the idea that we are created in the image of God, on this materialist view? Traditionally, being created in God's image has involved the notion of an immaterial soul. Corcoran, however, argues that such an understanding is no longer adequate, given both philosophical and scientific problems with dualism. Being made in the image of God means a lot of things. We, he suggests, 'image God when we care for creation', 'we image God when we live in a loving relation to other 
human beings' and when we 'invest ourselves in their flourishing and wellbeing' (Corcoran 2006: 81). Materialism does rule out a dualistic understanding of imago Dei, but not the various ways in which we image God in our lives (Corcoran 2006: 82). In this way, Corcoran seems to depart from what has been called the 'structural view of the image of God', according to which a specific component or capacity that humans possess ground their being in the image of God (Visala 2014: 102). Rather, Corcoran seems to adopt a performative or functional conception of imago Dei, suggesting that we humans act out our divine bearing and that we act as God's representatives on earth (see Deane-Drummond 2012; Van Huyssteen 2006: 132-136). Such an understanding puts less emphasis on who we are and more on what we are called to do.

\section{Some Philosophical Problems with Corcoran's Materialism}

Can Corcoran successfully defend his materialist ontology? I will argue for the following: Corcoran does not successfully ground intentional states and a first-person perspective in a materialist framework. Moreover, it seems as if Corcoran adheres to property dualism, but that such dualism does not fit his desired materialism.

An important task for a materialist is to show how particular properties fit a materialist/naturalist framework, and why we should prefer a materialist interpretation of, for example, mental properties, moral values, and higher-level properties in general. Corcoran provides, I suggest, good reasons for rejecting the nothing-but materialism. Reductive or eliminative materialists are unable to reduce higher-level phenomena, such as intentional states, capacity for first-person perspective, and that of being able to relate to other people. This is an important task, and I agree with Corcoran that these elements must be a part of any serious ontological consideration about what it means to be human. Corcoran, however, does not seem to actually ground intentionality and the subjectivity of consciousness in a materialist ontology. He remains strangely silent on a number of important issues: does his account amount to property dualism? Is there a supervenient relationship between intentional states and the material level? Is it appropriate, as the emergent theorist would have us think, to talk about human nature in terms of levels?

Corcoran does not use the term supervenience explicitly, but it seems that his materialist account must assume some notion of supervenience. In the body-mind debate, the concept of supervenience means that whatever happens on the mental level must correspond to some event on the physical level. Whatever mental event that takes place, it must correspond to some physical occurrence in the brain. The mental, therefore, supervenes on the physical. On Corcoran's account, intentional states should supervene on the 
physical and the intentional is ontologically dependent on the body (no biological body $\rightarrow$ no intentional states). This seems to follow from Corcoran's own constitution view and his claim that neuroscience demonstrates the intimate connection between the mental and the physical.

The problem with supervenience is that it does not amount to an explanation, and so mere ontological dependency is not enough to secure the constitution view. Jaegwon Kim helpfully explains that supervenience, by itself, cannot be considered a mind-body theory. He writes, 'the mere claim of mind-body supervenience leaves unaddressed the question what grounds or accounts for it - that is, the question why the supervenience relation should hold for the mental and the physical' (Kim 1998: 13). To apply this on the constitution view, to say that the person is constituted by the body, and ontologically dependent on it, does not explain how it is that something purely physical can give rise to intentional states and a robust first-person perspective. It seems as if this issue is left unanswered by Corcoran.

Another problem for a general supervenience thesis is that it does not secure, in this case, Corcoran's materialism. It seems as if it is compatible with a variety of other non-materialist frameworks/ontologies, including interactionist versions of dualism as well as dualistic understandings of emergence theory (which I will come back to later). In this way, the dependency of the mental upon the physical alone cannot show the constitution view to be correct and superior to non-materialist ontologies. Supervenience needs to be supplemented with some additional argument or positive reason for Corcoran's view to be convincing.

My second argument is that Corcoran is committed to property dualism. This in itself is not a problem, but it becomes one when the idea of irreducible properties is put together with materialism. Corcoran's view of the irreducibility of personhood means that there are particular properties, such as having the capacity for intentional states, which are not the same as purely physical states. While physical states persist, it is possible that intentional states cease to exist; hence, intentional states are not the same as and cannot be reduced to the physical level. Given this rejection of the reductionist identity thesis, as well as affirmation of the causal relevance of the mental, it is safe to assume that Corcoran holds to property dualism. Such dualism does not entail a robust Cartesian dualism. Instead, it claims that the world is made of one substance, yet there exists both physical and mental properties. But, how well does property dualism rhyme with a materialist ontology? Can someone who is a materialist about human creatures also maintain that there are irreducible mental properties?

A materialist who subscribes to property dualism with regard to the mental maintains that mental properties are irreducible with regard to the physical base level. Whatever properties that characterise a material sub- 
strate are not sufficient for capturing the nature of the mental domain. Their ontology, therefore, is in some sense extra-physical, or perhaps even non-physical. Hence, on a materialist reading of evolution there would be only material processes in play, interacting to bring about higher complexity. However, can a purely material process give rise to something extramaterial or non-material? Would there be, one should ask, any adaptive value with regard to such properties? (Lycan 2013: 537). Substance dualism is often accused of not being able to reconcile the idea of the origin of immaterial substances in light of evolution. Yet, it seems as if a property dualist that adheres to a strong notion of irreducibility faces a similar problem and is forced to produce some explanation for how mental properties can arise naturally from a thoroughly physical base level. Thus, we have an origin issue for this kind of property dualism.

There is also a compatibility issue that needs to be address, which pertains to how irreducible mental properties can be combined with a materialist ontology. First, we have to make one thing clear: mental properties exhibit features that are not like physical/material objects. Intentional states involve a subjective dimension unlike the objects that are 'revealed in ordinary sense perceptions or as uncovered in the physical and biological sciences' (O'Connor and Churchill 2010: 279). Being a conscious creaturepossessing intentionality, beliefs and desires- means that there is something like to be that creature. David Chalmers writes concerning this subjective dimension: 'To put it another way, we can say that a mental state is conscious if it has a qualitative feel-an associated quality of experience' (Chalmers 1996: 4). The problem for materialism is that such a qualitative feel does not seem to be derivable from material/physical properties. Indeed, Corcoran concedes this point in his constitution view: material stuff can persist while the mental does not, in a similar way to how some mass of bronze can persist despite the statue being shattered. In this way, Corcoran seems to admit that there is no relationship of derivability between the material and the mental, such that material properties necessitate mental properties.

However, if a material substance does not necessitate mental properties, what do we do with them? If they are not derivable, nor necessarily necessitated by material stuff, then how should we construe the ontology of mental properties? My suggestion is that if they are not derivable secondary properties, then they must be fundamental primary properties. As Susan Schneider argues, in order for the property dualist to explain the 'fundamental nature of the mind we must posit consciousness as a basic ingredient of the universe, alongside the fundamental physical properties' (Schneider 2012: 67). This would save the properties of consciousness from being eliminated. Nevertheless, such a philosophical move should be unacceptable for a materialist, as it would take property dualism in the direction of 
panpsychism - the view according to which mind and mental properties are fundamental constituents of reality. We maintain that Nancey Murphy's non-reductive physicalism invites a panpsychist understanding of consciousness (see Leidenhag 2016). To go down the panpsychist path is to abandon materialism as such, and many materialists would agree with this assessment. Thus, to hold to property dualism in the way that Corcoran seems to, undermines his materialist ontology.

There is another problem for Corcoran's materialist understanding of human nature. Corcoran emphasises the importance of relationality for his perspective, and for any serious philosophical and theological consideration of human nature. The Christian narrative stresses the importance of human beings forming relations: It is not good for a human to be alone, so God created another 'human being for the first to stand in relation to' (Corcoran 2006: 74). The Christian story further brings out the importance of a relationship with God, with non-human animals, and to creation as a whole. Thus, the Christian narrative, from the beginning to end, portrays human beings as persons-in relation (Corcoran 2006: 74). Relationality is, however, not just embedded in the Christian narrative, it is also 'causally essential to the emergence of a first-person perspective' (Corcoran 2006: 74). It is not just that the capacity for relationality is important for an adequate understanding of what it means to be a person, it is in fact in a 'deep sense constitutive of personhood' (Corcoran 2006: 75).

Thus, the capacity for relationality is causally necessary for talking about personhood. And it is this capacity that sets Corcoran's materialism apart from a reductive or eliminativist understanding of human nature. As Corcoran seems to suggest, relationality is a causal term in that it signifies a capacity for entering into relationships. Such capacity also involves intentionality; a person $S$ desires, for example, to enter into a relationship with person $Y$. That's why Corcoran wants to take his materialism away from the causal reductionism and determinism associated with harder forms of materialist/physicalist/naturalist ontologies. Such determinism is generally thought to be inconsistent with a Christian conception of what it means to be human, and being created in the image of God. Nancey Murphy, who proposes a very similar position to that of Corcoran, explains the need for causal anti-reductionism in this way:

The question of causal reduction seems to be the one that matters for retaining our traditional conceptions of personhood... First, if mental events can be reduced to brain events, and the brain events are governed by the laws of neurology (and ultimately by the laws of physics), then in what sense can we say that humans have free will?... Second, if mental events are simply the product of neurological causes, then what sense can we make of reasons? (Murphy 1998b: 131). 
This idea seems to be shared by Corcoran: a first-person perspective is essentially tied to the capacity for relationality, and if that capacity is incompatible with a materialist outlook on the nature of persons then his antireductionism collapses.

However, can Corcoran uphold this anti-reductionist view regarding relationality and intentional states in general? I suggest that he is unable to achieve this anti-reductionism and will argue: (1) his materialism makes intentional states causally impotent, (2) if intentional states lack causal efficacy then such states are turned into epiphenomena (they cannot be considered real in an ontological sense).

Mental causation is a tricky issue for materialism and it has frequently been used as an argument for dualism. A materialist is committed to the idea that material stuff should be sufficient for explaining mental phenomena; that is, it is not permissible to invoke any dualistic categories. However, if it is the case that material interactions can fully explain the reality of the mental, then what conceptual space is left for the idea of the causal efficacy of mental states? (Hasker 1999: 49) Jaegwon Kim, who I mentioned earlier in this paper, has formulated the principle of 'causal explanatory exclusion' to capture the problem of mental causation. He argues that 'there can be at most one complete and independent causal explanation, or one fully sufficient cause, for any single event' (Kim 1993: 291). The causal relevance of the mental becomes unclear if one suggests, as Corcoran does, that human creates are material through and through. A material cause, therefore, 'threatens to exclude, and pre-empt, the mental cause' (Kim 1998: 37). Because of this problem, the materialist is forced to provide a positive account of how a mental cause and a material cause of a particular event are causally and ontologically related to each other. That is, Corcoran needs to explicate more fully the supervenience relationship between mental properties and their material base, which brings us back to the first objection. I argued that this form of supervenience is not systematically or properly explained by Corcoran. More worryingly for the materialist, the chance for such an explanation does not seem promising. As Terence Horgan argues, it seems incredibly difficult to spell out how the material gives rise to the mental, and in what ways the mental supervenes on the material. He writes: 'Although a physical supervenience base might always exist for any manifestation of aboutness [intentionality], in general any adequate nonintentional, nonsemantic characterization of the supervenience base might be enormously baroque and complex' (Horgan 1994: 308). In order to characterize this relationship one might have to venture beyond the mind of the cognizer and include a vast external environment, perhaps it will include a massive number of physic-chemical interactions, and there might be no way to 
translate intentional states into nonintentional language. The problem, Horgan argues, seems insurmountable.

To conclude this section of the paper: Corcoran has offered an interesting critique of reductive materialism. Yet, he has not successfully defended, or explicated, his non-reductionist take on materialism. It is unclear how mental phenomena, which are essential for his view of personhood, relate to the material. Moreover, there are strong reasons for thinking that a materialist cannot make sense of the causally efficacy of mental states, and that his restrictive ontology negates any hint of property dualism. Due to these kinds of problems, it becomes increasingly difficult to separate Corcoran's constitution view from sheer reductionism.

\section{Philosophical and Theological Problems Regarding a Materialist Imago Dei}

It has been argued by Corcoran that materialism, at least on his nonreductive model, can accommodate the central Christian claim that humans are made in the imago Dei. There is, according to him, nothing about a constitution view of human nature that negates the belief that humans are created in the image of God. I argued earlier that Corcoran seems to side with a performative or functionalist understanding of Imago Dei, namely that to image God is a matter of doing, not simply being. An important aspect of this performativism is that humans should develop good relationships with other people, non-human animals, and creation. Before raising a philosophical problem with this account, I would like to point out some theological issues that need to be addressed.

The first issue that is in need of further clarification concerns people with autism whose ability for social interaction is affected. Autism is generally diagnosed by abnormalities in behaviour, although the reason for the emergence of autism is unclear. There is a growing consensus, however, that there is no single cause behind autism, and that it may 'involve multiple independent (though interacting) domains of neurological impairment' (Brown and Paul 2015: 111). According to contemporary research it looks as if disrupted 'connectivity or imbalance of connectivity [within the cortex] results in the limitations of social communication seen in autism' (Brown and Paul 2015: 112). The imago Dei, on the constitution view, is closely connected to the capacity for relationality, the ability to form relationships, and socially communicate with other people. How should we construe the notion of imago Dei with regard to people whose ability for social communication, and relating to other people, is impaired? This is not to say that Corcoran is unable to respond to such issues in a materialist manner, but that such an emphasis on relationality creates further questions. 
The second issue that I want to bring attention to is connected with the first one. If it is the case that certain people, for various reasons, are more or less apt at forming relationships, does that then mean that imago Dei is a matter of degree? Are some people simply better at imaging God in their daily lives and, if so, does that affect their status of being created in the image of God? It is often assumed in theological discourse that the status of imago Dei is absolute, that no external factor can undermine or challenge the idea that individuals bear the image of God. Once again, this is not to claim that Corcoran's ontology, by necessity, lacks the resources for responding to this issue. It is rather a call for clarification on the part of Christian materialism.

The third point that I want to bring up is in regard to the ontological dimension of the performative/functionalist/relational account proposed by Corcoran. Several people that turn towards relationalism in order to explain the 'image of God questions' do so because of the seeming problems with a dualist and structural/substantive account. It is claimed that such an account, whereby the imago Dei is construed in terms of particular capacities that are a part of our human nature (such as intellect, reason, and rationality), creates insurmountable metaphysical and scientific problems (Van Huyssteen 2006: 126). This turn from a substantivist to a relational understanding of what it means to be human, and being created by God, is claimed to sidestep some of the metaphysical problems of the former approach. For Alistair McFadyen, the substantive account 'indicates something definite, fixed and stable: something, usually within each individual, which constitutes us as human and characterizes substantial, essential humanity' (McFadyen 2012: 919).

The idea seems to be that one can sidestep some of the metaphysical problems associated with a substantive view of human nature by adopting, instead, a relational and functional ontology that places priority on us acting out divine imaging. I do not deny the value of such an account of the imago Dei, but it seems as if it too, in a similar way to the substantive view, encounters metaphysical issues. In stressing the relational character of human beings, Corcoran (and others in favour of comparable views) assumes a set of properties or capacities. That is, a person has the ability to enter into relationships with other people. This kind of ability consequently assumes the reality of relational properties, and such properties furthermore presuppose that we have certain capacities: 'If we did not have the capacity to love, we could not enter into loving relationships, if we did not have the ability to think and reason, we could not undertake a commission to be God's stewards on earth' (Stenmark 2012: 900). A relational property is also not a necessary property; it is possible for a human being to be constituted by nonrelational properties. That idea, as we have seen, is be shared by Corcoran's 
materialism. If it is the case, however, that a relational ontology presumes certain properties and that those properties, in turn, rely on cognitive capacities, then a materialist has to show how such properties and capacities can be ontologically explicated.

This, of course, takes us back to my three philosophical critiques of Christian materialism: (1) the supervenience relationship between mental states and material states are not explained, (2) property dualism is irreconcilable with materialism, and (3) materialism cannot uphold the causal relevance and efficacy of mental states. The performative / relational account of the imago Dei rests on certain philosophical assumptions about human nature that, while important for a robust conception of personhood, do not fit a materialist narrative of what it is that makes us human. There is a deep tension within Corcoran's materialism between his ontology and what he seeks to achieve in the theological domain. It seems as if we need to reject this materialism and pursue some other less restrictive framework for understanding human nature and human beings as being in created in God's image, even on a performative / functional interpretation of this doctrine. I have briefly described Corcoran's rejection of dualism and I will in the next section put his arguments against dualism under scrutiny.

\section{Evaluating Corcoran's Critique of Dualism}

Corcoran's push towards materialism is in part motivated by perceived problems with a dualistic account of the body-mind relationship. Earlier in the paper I hinted at a couple of reasons for Corcoran's rejection of dualism and we will now look at those reasons more closely.

Corcoran argues that dualism seems out of touch with contemporary science and that the mental-material relationship seems difficult to explain if one introduces an ontological distinction between mental and material causes. I suggest that Corcoran launches three arguments against dualism: (1) A dualist account of consciousness does not square with contemporary neuroscience which suggests a strong relationship of dependency between mind and matter; (2) Neuroscience shows that our capacity for complex experiences develops. But, as a soul lacks parts it cannot develop in any meaningful sense; (3) The intimate body-mind relationship makes the idea of a non-physical soul causally irrelevant.

Corcoran, in a similar way to other physicalists and materialists, points towards neuroscientific data and concludes that such data shows the superiority of materialism over dualism. What the field of neuroscience shows, according to Corcoran, is the intimate connection and fine-grained dependence between mental properties and the material states of and interactions in the brain. He provides examples from the neuroscientific literature that seemingly demonstrate how mental states are physically realized, how 
'distinct aspects of experience are implemented in anatomically neural structures' (Corcoran 2016: 155). The phenomenon of Blindsight is put forward as an example of this. Such condition 'renders patients who suffer from it able to 'see' without consciously seeing' (Corcoran 2016: 155). In such a scenario, a patient is shown a spot of light in their blind field of vision and asked 'what do you see?' The patient will, not unexpectedly, answer 'nothing'. Yet, if the patient is asked to locate the spot of light by pointing, then he/she can do it with very high precision. Thus, the patient is seeing without consciously seeing. This kind of fine-grained dependence of experience on neural activity, however, would not be possible on dualism, argues Corcoran. Indeed, 'the kind of neural activity mapped out by the neurosciences should be explanatorily irrelevant to its [conscious experiences] occurrence and character' (Corcoran 2016: 156). This gives us instead reasons to believe that all forms of experience are physically implemented, which speaks heavily against dualism.

This conclusion seems unwarranted for a few reasons. Even if there are mapped out correlations between mental and physical states, such correlation in itself does not answer the issue if physical states cause particular experiences. This is what Riccardo Manzotti and Paolo Moderato argue when they write:

Thanks to neuroscience, we know a lot more about the neural processes involved with arousal, sleep, memory, perception, free will, motor control, and imagery. Unfortunately, we don't know anything about the physical processes that give rise to consciousness or, more poignantly, about the physical processes that are consciousness itself (Manzotti and Moderato 2014: 87).

Correlation, as suggested by Corcoran, does not answer if mental content can be reduced to physical causation. This kind of neuroscientific account that Corcoran appeals to does not explain the nature of the correlation, and it does not show why it is the case that some physical process should bring about a mental state. Indeed, the correlation is left unexplained and treated as a brute fact. In a similar way to how supervenience is not properly explained, neither is this correlation. In this way, Corcoran's materialism is brought closer to what has been called mysterianism; that is, it is simply a mystery how the mental emerges from the brain (Flanagan 1992: 8-11). What Corcoran needs to demonstrate is that every mental event is sufficiently physically caused. But such a task does not seem achievable. It is, for example, logically possible for a mental event to take place without any correspondence to a neurological event in the brain. This is, I confess, a speculative idea but it is certainly possible for mental event $Y$, in the logical sense, to obtain without a correlation to physical event $X$. 
This objection from neuroscience raises a further issue to consider: Is mental-physical correlation really a problem for a committed dualist? Dualism comes in many versions and some would accommodate brain correlations better than others. I want to suggest that an articulation of dualism that takes seriously the embodiment of human creatures can respond to Corcoran's neuroscientific critique in an adequate way. Both Charles Taliaferro's intergrative dualism and William Hasker's emergent dualism seem to be up to the task. On Taliaferro's dualism, there is not radical bifurcation between the person and the body; instead, a healthy person is an embodied functional unity that interacts with the world through his/her body (Taliaferro 2014: 198). When I kiss my wife it is not simply a soul kissing her. For a kiss to be possible there needs to be a 'combination of intentional movement, embodiment, and expression' (Taliaferro 2014: 198).

Nevertheless, the mental realm is ontologically fundamental and irreducible to whatever the sciences reveal about the physical world, and so this position falls within the dualistic category of mind-body frameworks. This is similar to Hasker's emergent dualism. This dualism starts from an emergentist conception of the mind. The mind is an emergent phenomenon in that it appears due to interactions at the physical level. But, compared to other versions of emergentism, Hasker maintains something stronger than just the appearance of a new property. The emergence of mind amounts to a new substance, or what he dubs an emergent individual (Hasker 1999: 188-197). Emergent dualism, thus, combines the basic emergentist idea, that consciousness is intimately connected with the physical, with the substance metaphysics that is generally taken to be constitutive of dualism.

It seems as if Corcoran's critique falls short in light of an intergrative or emergent conception of dualism. Taliaferro's and Hasker's proposals do not assume an unbridgeable gap between mind and body, nor do they subscribe to the 'ghost in the machine' type of dualism. A dualism according to which persons are holistic unities would expect there to be mentalphysical correlation, it would not come across as an ontological anomaly; on the contrary, such correlation follows from the basic ontological commitments of what it means to be a person.

Corcoran argues, moreover, that emergence of more complex experiencing and more complex conscious capacities seem better fitted to materialism. But, if the dualist picture is true then this gradual development seems very problematic as it is hard to imagine how a non-physical and partless soul can develop in any meaningful sense. How should we respond to this objection? I think, similarly to his first objection, that this anti-dualist critique seems to be based on a non-interactionist and Carte- 
sian form of dualism. Hence, given this gap between the mental and the material, it is very hard to make sense of increasingly complex mental states and experiences.

What Taliaferro and Hasker show, though, is that a dualist can happily concede the reality of mind-brain correlation. It seems further possible to maintain the gradual development of more complex forms of experiences. While the soul as such does not develop (or increases or decreases in any particular capacity), when matter is suitably configured it allows for multifaceted mental states and more complex causal interactions with the world. An interactionist model, furthermore, provides a two-way model for the mind-brain relationship, whereby the increased complexity in the brain not only allows for more complex experiences, but that a particular 'field of consciousness in turn modifies and directs the functioning of the physical brain' (Hasker 1999: 195). It is often claimed that a dualist cannot make sense of the evolutionary development of consciousness. Richard Swinburne, another prominent dualist, argues that such claims are unfounded. It is perfectly coherent for a dualist to argue that during the course of evolution the soul gradually passes 'from being passive and structureless, to being structured and active, structured by causally influential beliefs and desires. Mutations of genes gave rise to organisms with brains which in certain environmental circumstances occupied states which gave rise to sophisticated and causally efficacious desires in the soul' (Swinburne 2007: 297). Of course, the critic could retort and say that the possibility of more complex experiences is due solely to the difference in relationships between material constituents, and that the concept of a soul brings nothing to the table. The 'soul talk' would be epiphenomenal.

This brings us to Corcoran's third critique, that the soul is causally and explanatorily irrelevant. The thrust of this critique is that the more we find out about the neural activities of the brain, the more explanatorily irrelevant a nonphysical soul appears. Contrary to this critique, I maintain that the soul is not only explanatorily relevant for explaining mental life, but that it is indispensable for explaining the successfulness of human practices.

We have seen that materialism, even on Corcoran's non-reductive account, is unable to make sense of the causal efficacy of mental states. Materialism makes such mental states ontologically dependent on the physical happenings of the brain and, hence, causally redundant. This is the problem of epiphenomenalism, that a mental state is a mere by-product of 'neurophysiological causes of behaviour that does not itself contribute anything to 'the go' of the world' (Walter 2009: 85). As I explained earlier in this paper, through Kim, if one holds that there is only physical-to-physical causation, then the mental becomes ontologically superfluous. Indeed, to 
maintain that there are events that do not have physical causes would be to concede the defeat and insufficiency of a materialist anthropology. Epiphenomenalism is caused by an overly restrictive ontology that views material properties as the basic stuff of reality, and so the solution seems to be to find an ontology that can make sense of why there are mental properties and how such properties allow for human creatures (and possible other high-level animals) to have agency and free will. Moreover, we intuitively view ourselves as autonomous agents, and it seems as if mental causation is integral to the 'manifest image'. Dualism, in virtue of being less restrictive, seems more able than a materialist ontology to explain the reality of mental causation, how it is that we can affect our environment. In matters of explanation dualism is not irrelevant, for it can shed light on the relationship between mind and reality, how it is possible for the mind to 'hook up' with an external environment.

In addition to providing ontological resources for explaining causal powers of mental properties, dualism is explanatorily relevant in the sense that it can account for the unity of consciousness. When we have a conscious experience, we might have a multiplicity of them: we might smell something delicious, spot a beautiful tree, and feel pain, all at the same time. The interesting thing is that these experiences are connected in a significant way; they are unified and seem to belong to a single state of consciousness. In a healthy state, free from neurophysiological disorders, we interact with the world as a unified subject. But how can we explain this phenomenon of unity if, as it is claimed on materialism, that our conscious experiences are a product of a multitude of neurological firings and interactions in the brain? Such multiplicity of physical happenings, it seems, should give rise to a multiplicity of disparate experiences. This speaks strongly against a materialist understanding of mind, whereby 'I' am in some sense identical to or (as Corcoran claims) constituted by physical processes. The situation seems to be this, 'whatever properties we encounter in the world, these properties are co-presented for us in a unified experience-or, we may also say, to a single subject' (Hasker 1999: 134). This subject, moreover, cannot be identical to the physical processes within the body for such identitism would lead us back to the unity-of-consciousness problem. The subject must be ontologically independent of such processes. This does not constitute a proof of dualism, but I make this argument to show, once again, the deficiency of materialism and the explanatory prospects for a dualism that regards consciousness as irreducible to the physical.

Lastly, a form of dualism that maintains the irreducible character of a first-person perspective seems indispensable for our human practices. Intentional psychological properties make it possible to have beliefs about 
reality, and they make it possible to 'deliberate about ends and means, and assess the rationality of actions and decisions' (Kim 1993: 214). Intentionality makes normative and evaluate practices philosophically coherent and practically possible. However, I argued that materialism ends up denying intentional states, and undermining the reality of consciousness. Such a conclusion, however, is devastating for the coherency of materialism. Corcoran, in his materialist philosophical endeavour, is engaged in an evaluative practice, assessing the rationality of dualism and makes positive arguments for materialism. To base one's intellectual practice, such as philosophy, theology or science, on an ontological framework that ends up (as I have argued) excluding the mental realm is devastating and leads to incoherence. Corcoran, as a philosopher, seeks intellectual clarification, but such a practice of clarification is not possible given a materialism that significantly casts doubt about the reality of consciousness. The mental realm, and the reality of intentionality, is assumed in several central human practices, but such an assumption cannot be squared with materialism. This does not prove dualism per se-indeed it is compatible with both panpsychism and idealism-but it takes us away from the limited framework of materialism and the constitution view proposed by Corcoran.

\section{Conclusions}

The purpose of this paper has been to offer a critical evaluation of Kevin Corcoran's Christian Materialism. I have argued that his constitution view is unable to support a robust first-person perspective and intentional states, as well as the causal efficacy of the mind. Hence, Corcoran's anthropology comes dangerously close to the kind of reductionism that he seeks to escape. It was also seen that his account of the imago Dei contained both philosophical and theological problems. I also evaluated Corcoran's critique of dualism. Based on William Hasker's and Charles Taliaferro's embodied dualisms, I suggested that Corcoran's critique falls short and that dualism remains a viable option in both philosophy and theological anthropology.

\section{Bibliography}

Brown WS and Paul LK (2015) Brain Connectivity and the Emergence of Capacities of Personhood: Reflections from Callosal Agnesis and Autism. In Jeeves M (ed.) The Emergence of Personhood: A Quantum Leap? Grand Rapids, MI: William B Eerdmans.

Corcoran KJ (1999) Persons, Bodies, and the Constitution Relation. The Southern Journal of Philosophy 37(*): 1-20. 
Corcoran KJ (2006) Rethinking Human Nature: A Christian Materialist Alternative to the Soul. Grand Rapids, MI: Baker Academic.

Corcoran KJ (2016) A Materialist View of Human Persons and Belief in the Afterlife. Modern Believing 57(*): 153-161.

Deane-Drummond C (2012) God's Image and Likeness in Humans and Other Animals: Performative Soul-Making and Graced Nature. Zygon: Journal of Religion and Science 47(*): 934-948.

Flanagan O (1992) Consciousness Reconsidered. Cambridge, MA: The MIT Press.

Hasker W (1999) The Emergent Self. Ithaca and London: Cornell University Press.

Horgan T (1994) Naturalism and Intentionality. Philosophical Studies 76 : 301-326.

Kim J (1993) Supervenience and Mind: Selected Philosophical Essays. Cambridge and New York: Cambridge University Press.

Kim J (1998) Mind in a Physical World: An Essay on the Mind-Body Problem and Mental Causation. Cambridge, MA: The MIT Press.

Leidenhag M (2016) From Emergence Theory to Panpsychism: A Philosophical Evaluation of Nancey Murphy's Non-reductive Physicalism. Sophia: International Journal of Philosophy and Traditions 55(*): 381-394.

Lycan W (2013) Is Property dualism better off than substance dualism? Philosophical Studies 164(*): 533-542.

Manzotti R and Moderato P (2014) Neuroscience: Dualism in Disguise. In Lavazza A and Robinson H (eds.) Contemporary Dualism: A Defence. New York and London, NY: Routledge.

McFadyen A (2012) Imaging God: A Theological Answer to the Anthropological Question? Zygon: Journal of Religion and Science 47(*): 918-933.

Murphy N (1998a) Human Nature: Historical, Scientific, and Religious Issues. In Brown WS, Murphy N, and Malony HN (eds) Whatever Happened to the Soul? Scientific and Theological Portraits of Human Nature. Minneapolis, MN: Fortress Press.

Murphy N (1998b) Nonreductive physicalism: Philosophical Issues. In Brown WS, Murphy N, and Malony HN (eds) Whatever Happened to the Soul? Scientific and Theological Portraits of Human Nature. Minneapolis, MN: Fortress Press.

O'Connor T and Churchill JR (2010) Nonreductive Physicalism or Emergent Dualism? The Argument from Mental Causation. In Coons RC and Bealer G (eds) The Waning of Materialism. Oxford and New York: Oxford University Press.

Schneider S (2012) Why property dualists must reject substance physicalism. Philosophical Studies 157(*): 61-76. 
Stenmark M (2012) Is There a Human Nature? Zygon: Journal of Religion and Science 47(*): 890-902.

Swinburne R (2007) The Evolution of The Soul [Revised Edition]. Oxford: Clarendon Press.

Taliaferro C (1994) Consciousness and the Mind of God. Cambridge and New York: Cambridge University Press.

Taliaferro C (2014) The Promise and Sensibility of Integrative Dualism. In Lavazza A and Robinson H (eds) Contemporary Dualism: A Defense. New York and London: Routledge.

Van Huyssteen WJ (2006) Alone in the World? Human Uniqueness in Science and Theology. Grand Rapids, MI: William B. Eerdmans.

Visala A (2014) Imago Dei, Dualism, and Evolution: A Philosophical Defense of the Structural Image of God. Zygon: Journal of Religion and Science 49(*): 101-120.

Walter S (2009) Epiphenomenalism. In McLaughlin BP, Beckermann A and Walter S (eds) The Oxford Handbook of Philosophy of Mind. Oxford: Clarendon Press. 